\title{
Studies on the Glomerular Filtration
}

\section{On the Glomerular Filtration in Cases of Exudative Pleurisy, Especially on the Cause of Water Diuresis}

By

\author{
Kietsu Igarashi \\ (五十嵐 喜悦)
}

(From the Medical Cinlic of Prof. F. Nakazawa, Faculty of Medicine, Tohoku University, Sendai)

(Received for publication, July 9, 1951)

\section{INTRODUCTION}

Many factors concern the increase and decrease of the quantity of urine, but the production of it in the kidney is influenced by the following four factors; that is, the increase and the decrease of the quantity of filtration in the glomeruli, the increase and the decrease of the quantity of reabsorption in the tubuli. Thereupon I tried this experiment as I thought it clinically and pathologic-physiologically important to investigate the glomerular filtration and the tubular reabsorption concerning two or three medical diseases, the prognostic significance of which can be judged from the increase and decrease of the quantity of urine. In Part I, I report my studies on pleurisy.

It has been well known that in the case of pleurisy the quantity of urine decreases in the excretion state of exudate and increases in the absorption stage. Therefore it is very helpful for its prognosis and treatment to know the condition of water metabolism of the body and thereby to presume the acute stage or the absorption stage of the disease.

In 1924 Peyrer $^{1)}$ for the first time applied water test to pleuritic patients for the purpose of finding the acute stage or the absorption stage of pleurisy, and recognized its significance. Greuel ${ }^{2)}$ also making a similar experiment and comparing it with blood sedimentation rate and temperature, emphasized its significance. This is supported by Mumme ${ }^{3)}$ and some japanese scholars f.i. Hirai. ${ }^{4)-8}$ But there have been very few experimental reports of water test on pleuritic patients. There is only one report made by Okazaki ${ }^{9}$ in 1926 , but the result of his examination is not very clear. Moreover in any of their water tests the relation between the change of the quantity of urine and the mechanism of urine production in the kidney is entirely unknown. Therefore I tried my water test on those pleuritic 
patients who entered Prof. Nakazawa's medical clinic in and after 1946, simultaneously estimating glomerular filtration and reabsorption of the kidney and investigated its significance.

\section{EXPERIMENTAL}

\section{Material and Method}

Out of the patients who entered Prof. Nakazawa's medical clinic in and after 1946, I chose 30 genuine wet pleuritic patients, excluding such patients as might mistake my judgment on the result of experiment: i.e. those with pulmonary tuberculosis, those with high temperature and profuse sweating, those with edema caused by kidney or heart trouble, and those with diarrhea or constipation were eliminated. Following Volhard, I examined the diluting and concentrating power of the kidney and estimated glomerular filtration (GF) and reabsorption of the kidney (RR) per minute during the period in which secretion of urine is imagined greatest, and at the same time I calculated reabsorption percent of the kidney (RR \%). As Volhard did, I gave the patient 1,000 cc. of water in 10 minutes after emptying the bladder at 8 a.m., and then $I$ took the excretion of urine every 30 minutes before noon and every 2 hours after noon till 8 p.m., moreover adding the all excretion till $8 \mathrm{a}$.m. of the next morning. I estimated the quantity and specific gravity of this urine. As to the estimation of GF, I followed Rehberg's ${ }^{10)}$ principle; but without loading creatinine, I made a calculation by the following formula in consideration of the quantity of urine produced in an hour from 9 a.m. till $10 \mathrm{a} . \mathrm{m}$. and the density of the urine and blood creatinine ( $\mathrm{Cu} \& \mathrm{Cp}$ ).

$$
\mathrm{GF}=\frac{\mathrm{U}}{60} \times \frac{\mathrm{Cu}}{\mathrm{Cp}} \quad \mathrm{RR}=\mathrm{GF}-\frac{\mathrm{U}}{60} \quad \mathrm{RR} \%=\frac{\mathrm{RR}}{\mathrm{GF}} \times 100
$$

Of course during the experiment the patient was given only dried food.

\section{Results}

As control investigation I chose 20 healthy persons who had no past history of kidney trouble. Each of the water tests is normal (Tab. I). Average GF is $167.8 \mathrm{cc}$. and RR\% is 92.5 (Tab. II).

According to Nakazawa and Kusakari11) GF of healthy persons is $160-190$ cc. and RR\% is 99.3 and according to Asano ${ }^{12)}$ who does not load creatinine $\mathrm{RR} \%$ is almost the same, but GF is so small as $107.3 \mathrm{cc}$. I myself, making an estimation of 20 healthy persons without doing water test or loading creatinine, had the value of GF $129.5 \mathrm{cc}$. and RR \% 98.6. Comparing this value with that of water test, I found that by water test the value of GF increases and $\mathrm{RR} \%$ decreases. This result is significant, the probability of error being below $1 \%$. This shows the same tendency 
TABLE I

\begin{tabular}{|c|c|c|c|c|c|c|c|c|}
\hline \multirow{2}{*}{$\begin{array}{l}\text { No. } \\
\text { of } \\
\text { case }\end{array}$} & \multirow{2}{*}{ Age } & \multirow{2}{*}{ Sex } & \multirow{2}{*}{$\begin{array}{l}\text { Quant. of } \\
\text { urine in } \\
4 \text { hours (cc.) }\end{array}$} & \multirow{2}{*}{$\begin{array}{l}\text { Quant. of } \\
\text { urine in } \\
\text { first } 2 \text { hours } \\
\text { (cc.) }\end{array}$} & \multirow{2}{*}{$\begin{array}{c}\text { Quant. of } \\
\text { urine in } \\
24 \text { hours (cc. }\end{array}$} & \multirow{2}{*}{$\begin{array}{l}\text { Maximum } \\
\text { quant. of } \\
\text { urine in half } \\
\text { an hour (cc.) }\end{array}$} & \multicolumn{2}{|c|}{ Specific gravity } \\
\hline & & & & & & & Max. & Min. \\
\hline 1 & 23 & ชิ & 1860 & 1385 & 2375 & 515 & 1,031 & 1,000 \\
\hline 2 & 30 & $\delta$ & 1720 & 1135 & 2220 & 440 & 1.030 & 1,002 \\
\hline 3 & 41 & 今 & 1800 & 1460 & 2340 & 470 & 1,030 & 1,004 \\
\hline 4 & 17 & 今ิ & 1310 & 1015 & 1655 & 435 & 1,034 & 1,001 \\
\hline 5 & 16 & $\delta$ & 1285 & 935 & 1825 & 350 & 1,030 & 1,004 \\
\hline 6 & 25 & 송 & 1635 & 1345 & 2050 & 465 & 1,029 & 1,000 \\
\hline 7 & 30 & 호 & 1770 & 1425 & 2170 & 490 & 1,030 & 1,000 \\
\hline 8 & 27 & $\hat{\sigma}$ & 1635 & 1325 & 2045 & 480 & 1,028 & 1,000 \\
\hline 9 & 34 & 今 & 1455 & 1095 & 1840 & 410 & 1,030 & 1,002 \\
\hline 10 & 38 & $\delta$ & 1270 & 950 & 1760 & 360 & 1,028 & 1,002 \\
\hline 11 & 37 & 우 & 1075 & 855 & 1635 & 420 & 1,027 & 1,001 \\
\hline 12 & 22 & 우 & 1250 & 945 & 1600 & 350 & 1,030 & 1,002 \\
\hline 13 & 31 & ㅇ & 1390 & 745 & 1735 & 360 & 1,030 & 1,004 \\
\hline 14 & 20 & 우 & 1345 & 1135 & 1675 & 460 & 1,032 & 1,001 \\
\hline 15 & 20 & 우 & 1405 & 1140 & 1825 & 580 & 1,028 & 1,000 \\
\hline 16 & 23 & 우 & 1245 & 980 & 1605 & 420 & 1,030 & 1,001 \\
\hline 17 & 22 & \% & 1500 & 1100 & 1815 & 400 & 1,030 & 1,001 \\
\hline 18 & 45 & 우 & 1170 & 860 & 1660 & 390 & 1,028 & 1,002 \\
\hline 19 & 38 & 우 & 1295 & 755 & 1750 & 360 & 1,030 & 1,001 \\
\hline 20 & 25 & 우 & 1220 & 910 & 1640 & 400 & 1,028 & 1,001 \\
\hline & 1432 & 1075 & 1861 & 427 & & \\
\hline
\end{tabular}

with the result once obtained by Hiratsuka ${ }^{13)}$ under Prof. Nakazawa's direction.

I divided the result of the water test on the pleuritic patients into 3 groups. The first group consists of those that are in the acute stage according to the clinical picture, the quantity of urine in 4 hours being much less than the dosis of drinking water. The second group consists of those that are still far from absorption stage though there is no symptom of being in clinically acute stage, the quantity of urine in 4 hours being nearly the same as the dosis of drinking water. The third group consists of those that are already in clinically absorption stage, the quantity of urine in 4 hours being much more than the dosis of drinking water.

1. The first group: acute stage (Tab. III, IV)

The excretion of water is prevented; the average quantity of urine in 4 hours is $568 \mathrm{cc}$., which is less than $\frac{1}{2}$ of the normal quantity. The excretion of water reaches maximum within the first 2 hours, but the maxi- 
TABLE II

\begin{tabular}{|c|c|c|c|c|c|c|c|c|c|c|}
\hline \multirow{2}{*}{$\begin{array}{l}\text { No. } \\
\text { of } \\
\text { case }\end{array}$} & \multirow{2}{*}{ Age } & \multirow{2}{*}{ Sex } & \multicolumn{2}{|c|}{ Urine an hour } & \multicolumn{2}{|c|}{$\begin{array}{l}\text { Creatinine } \\
\mathrm{mg} / \mathrm{dl}\end{array}$} & \multirow{2}{*}{$\begin{array}{l}\text { Quant. of } \\
\text { urine per } \\
\text { min. cc. }\end{array}$} & \multirow{2}{*}{$\begin{array}{l}\text { GF } \\
\text { cc. }\end{array}$} & \multirow{2}{*}{$\begin{array}{l}\mathrm{RR} \\
\text { cc. }\end{array}$} & \multirow{2}{*}{$\underset{\%}{\mathrm{RR}}$} \\
\hline & & & $\begin{array}{l}\text { Quant. of } \\
\text { urine }(c c .)\end{array}$ & $\begin{array}{c}\text { Specific } \\
\text { gravity }\end{array}$ & Urine & Plasma & & & & \\
\hline 1 & 23 & $\delta$ & 980 & 1,000 & 10,51 & 0,80 & 16,3 & 214,0 & 197,7 & 92,3 \\
\hline 2 & 30 & $\hat{\delta}$ & 810 & 1,002 & 9,38 & 0,53 & 13,5 & 238,9 & 225,4 & 94,3 \\
\hline 3 & 41 & $\delta$ & 905 & 1,004 & 10,40 & 0,85 & 15,0 & 181,1 & 166,1 & 91,6 \\
\hline 4 & 17 & $\hat{\delta}$ & 650 & 1,001 & 8,13 & 0,67 & 10,8 & 131,0 & 120,2 & 91,7 \\
\hline 5 & 16 & 今 & 590 & 1,004 & 12,45 & 0,61 & 9,8 & 187,7 & 177,9 & 94,7 \\
\hline 6 & 25 & s & 890 & 1,000 & 7,59 & 0,77 & 14,8 & 145,8 & 131,0 & 89,8 \\
\hline 7 & 30 & 今 & 920 & 1,000 & 8,26 & 0,82 & 15,4 & 155,1 & 139,7 & 90,0 \\
\hline 8 & 27 & 8 & 850 & 1,001 & 9,06 & 0,78 & 14,1 & 163,7 & 149,6 & 91,3 \\
\hline 9 & 34 & $\delta$ & 720 & 1,002 & 9,53 & 0,62 & 12,0 & 184,2 & 172,1 & 93,4 \\
\hline 10 & 38 & $\delta$ & 600 & 1,002 & 11,75 & 0,65 & 10,0 & 180,7 & 170,7 & 94,4 \\
\hline 11 & 37 & 우 & 620 & 1,001 & 10,50 & 0,83 & 10,3 & 130,3 & 120,0 & 92,0 \\
\hline 12 & 22 & 운 & 595 & 1,004 & 14,10 & 0,78 & 9,9 & 178,9 & 169,0 & 94,4 \\
\hline 13 & 31 & 우 & 590 & 1,004 & 9,34 & 0,60 & 9,8 & 152,5 & 142,7 & 93,5 \\
\hline 14 & 20 & 우 & 810 & 1,001 & 7,98 & 0,63 & 13,5 & 171,0 & 157,5 & 92,1 \\
\hline 15 & 20 & 우 & 960 & 1,000 & 7,19 & 0,65 & 16,0 & 176,9 & 160,9 & 90,9 \\
\hline 16 & 23 & 우 & 680 & 1,002 & 10,32 & 0,76 & 11,3 & 153,4 & 142,1 & 92,6 \\
\hline 17 & 22 & 우 & 750 & 1,001 & 9,75 & 0,72 & 12,5 & 167,9 & 155,4 & 92,5 \\
\hline 18 & 45 & 우 & 650 & 1,002 & 11,06 & 0,81 & 10,8 & 147,4 & 136,6 & 92,6 \\
\hline 19 & 38 & 우 & 580 & 1,002 & 11,07 & 0,75 & 11,3 & 141,6 & 132,0 & 93,2 \\
\hline 20 & 25 & 우 & 630 & 1,001 & 10,31 & 0,68 & 10,5 & 154,6 & 144,1 & 93,2 \\
\hline \multicolumn{3}{|c|}{ Average } & 739 & & 9,93 & 0,71 & 12.4 & 167,8 & 155,4 & 92,5 \\
\hline
\end{tabular}

TABLE III

\begin{tabular}{|c|c|c|c|c|c|c|c|c|}
\hline \multirow{2}{*}{$\begin{array}{l}\text { No. } \\
\text { of } \\
\text { case }\end{array}$} & \multirow{2}{*}{ Age } & \multirow{2}{*}{ Sex } & \multirow{2}{*}{$\begin{array}{l}\text { Quant. of } \\
\text { urine in } \\
4 \text { hours } \\
\text { (cc.) }\end{array}$} & \multirow{2}{*}{$\begin{array}{l}\text { Quant. of } \\
\text { urine in } \\
\text { first } 2 \\
\text { hours (cc.) }\end{array}$} & \multirow{2}{*}{$\begin{array}{l}\text { Quant. of } \\
\text { urine in } \\
24 \text { hours } \\
\text { (cc.) }\end{array}$} & \multirow{2}{*}{$\begin{array}{l}\text { Maximum } \\
\text { quant. of } \\
\text { urine in half } \\
\text { an hour (cc.) }\end{array}$} & \multicolumn{2}{|c|}{ Specific gravity } \\
\hline & & & & & & & Max. & Min. \\
\hline 1 & 19 & $\hat{o}$ & 205 & 124 & 815 & 35 & 1,032 & 1,024 \\
\hline 2 & 25 & s & 495 & 285 & 1250 & 135 & 1,032 & 1,014 \\
\hline 3 & 29 & 우 & 580 & 395 & .1035 & 150 & 1,030 & 1,012 \\
\hline 4 & 19 & 우 & 585 & 485 & 745 & 225 & 1,032 & 1,002 \\
\hline 5 & 59 & 우 & 590 & 385 & 990 & 185 & 1,024 & 1,008 \\
\hline 6 & 32 & 우 & 740 & 630 & 1080 & 240 & 1,030 & 1,006 \\
\hline 7 & 21 & ㅇ & 780 & 470 & 1205 & 215 & 1,030 & 1,006 \\
\hline \multicolumn{3}{|c|}{ Average } & 568 & 396 & 1017 & 169 & & \\
\hline
\end{tabular}


TABLE IV

\begin{tabular}{|c|c|c|c|c|c|c|c|c|c|c|}
\hline \multirow{2}{*}{$\begin{array}{l}\text { No. } \\
\text { of } \\
\text { case }\end{array}$} & \multirow{2}{*}{ Age } & \multirow{2}{*}{ Sex } & \multicolumn{2}{|c|}{ Urine an hour } & \multicolumn{2}{|c|}{$\begin{array}{l}\text { Greatinine } \\
\mathrm{mg} / \mathrm{dl}\end{array}$} & \multirow{2}{*}{$\begin{array}{l}\text { Quant. of } \\
\text { urine per } \\
\text { min. cc. }\end{array}$} & \multirow{2}{*}{$\begin{array}{l}\text { GF } \\
\text { cc. }\end{array}$} & \multirow{2}{*}{$\begin{array}{l}\mathrm{RR} \\
\mathrm{cc} .\end{array}$} & \multirow{2}{*}{$\underset{\%}{\mathrm{RR}}$} \\
\hline & & & $\begin{array}{l}\text { Quant. of } \\
\text { urine cc. }\end{array}$ & $\begin{array}{l}\text { Specific } \\
\text { gravity }\end{array}$ & Urine & Plasma & & & & \\
\hline 1 & 19 & $\delta$ & 62 & 1,024 & 111,67 & 1,14 & 1,0 & 97,9 & 96,9 & 98,8 \\
\hline 2 & 25 & $\hat{\sigma}$ & 135 & 1,014 & 57,33 & 1,27 & 2,2 & 99,3 & 97,1 & 97,6 \\
\hline 3 & 29 & 우 & 270 & 1,012 & 18,06 & 0,85 & 4,5 & 95,6 & 91,1 & 95,3 \\
\hline 4 & 19 & 우 & 330 & 1,002 & 17,59 & 0,78 & 5,5 & 124,0 & 118,5 & 95,5 \\
\hline 5 & 59 & 우 & 125 & 1,010 & 12,66 & 0,59 & 2,0 & 42,9 & 40,9 & 95,3 \\
\hline 6 & 32 & 우 & 460 & 1,006 & 14,83 & 0,88 & 7,6 & 128,0 & 120,4 & 94,0 \\
\hline 7 & 21 & 우 & 325 & 1,006 & 22,53 & 0,96 & 5,4 & 126,7 & 121,3 & 95,7 \\
\hline & & & 244 & & 36,38 & 0,92 & 4,0 & 102,0 & 98,0 & 96,0 \\
\hline
\end{tabular}

mum quantity of urine in half an hour averages $169 \mathrm{cc}$., which shows less than $1 / 3$ of the dosis of drinking water. In 3 cases the quantity of urine in 24 hours does not reach the dosis of drinking water, and in 4 cases it shows delay, incomplete reaction. The minimum specific gravity except 1 case is above 1,004 and the diluting power of the kidney is prevented, and the maximum specific gravity is normal except 1 case. Besides, there is 1 case that excretes $20-30 \mathrm{cc}$. of urine with high specific gravity every 30 minutes all through the course. Next, average GF is $102.0 \mathrm{cc}$., and RR\% is 96.0 which shows that though GF decreases, $\mathrm{RR} \%$ increases. This fact proves that, in the water test, the diluting power is prevented and that the concentrating power is normal. The decrease of $\mathrm{GF}$ and the increase of RR \% show statistically that the probability of error is below $1 \%$ and so it is significant. Therefore it is clear that though the oliguria is mainly due to the decrease of GF, it is partly due to the increase of $R R$.

\section{The second group: middle stage (Tab. V, VI)}

The excretion of water is considerably better than that in the acute stage. The quantity of urine in 4 hours averages $1080 \mathrm{cc}$., which is almost normal. In 4 cases the maximum quantity of urine in half an hour is above $1 / 3$ of the dosis of drinking water. In 5 cases the quantity of urine in 24 hours is above $1,500 \mathrm{cc}$., and shows delay, excessive reaction; and in 4 cases it shows delay, incomplete reaction. The minimum specific gravity is a little prevented in 3 cases, but the maximum specific gravity is normal respectively. GF averages $144.2 \mathrm{cc}$., which is considerably more than that in the acute stage, but is less than the normal value. This decrease of GF shows statistically that the probability of error is below $5 \%$ and so it is significant. RR averages $93.0 \%$ and so it is nearly normal. Therefore in the middle stage, though GF decreases, RR suppression is almost 
TABLE V

\begin{tabular}{|c|c|c|c|c|c|c|c|c|}
\hline \multirow{2}{*}{$\begin{array}{l}\text { No. } \\
\text { of } \\
\text { case }\end{array}$} & \multirow{2}{*}{ Age } & \multirow{2}{*}{ Sex } & \multirow{2}{*}{$\begin{array}{l}\text { Quant. of } \\
\text { urine in } \\
4 \text { hours } \\
\text { (cc.) }\end{array}$} & \multirow{2}{*}{$\begin{array}{l}\text { Quant. of } \\
\text { urine in } \\
\text { first } 2 \\
\text { hours (cc.) }\end{array}$} & \multirow{2}{*}{$\begin{array}{l}\text { Quant. of } \\
\text { urine in } \\
24 \text { hours } \\
\text { (cc.) }\end{array}$} & \multirow{2}{*}{$\begin{array}{l}\text { Maximum } \\
\text { quant. of } \\
\text { urine in half } \\
\text { an hour (cc. })\end{array}$} & \multicolumn{2}{|c|}{ Specific gravity } \\
\hline & & & & & & & Max. & Min. \\
\hline 1 & 19 & $\delta$ & 890 & 775 & 1435 & 330 & 1,032 & 1,003 \\
\hline 2 & 24 & 무 & 913 & 747 & 1186 & 305 & 1,032 & 1,006 \\
\hline 3 & 22 & 우 & 1045 & 915 & 1220 & 350 & 1,034 & 1,003 \\
\hline 4 & 46 & $\delta$ & 1055 & 935 & 1580 & 350 & 1,031 & 1,002 \\
\hline 5 & 52 & 今 & 1066 & 883 & 1691 & 345 & 1,027 & 1,003 \\
\hline 6 & 22 & $\delta$ & 1090 & 640 & 1357 & 270 & 1,033 & 1,005 \\
\hline 7 & 29 & 우 & 1137 & 837 & 1501 & 405 & 1,036 & 1,002 \\
\hline 8 & 46 & $\delta$ & 1235 & 915 & 1775 & 330 & 1,028 & 1,002 \\
\hline 9 & 25 & $\delta$ & 1295 & 970 & 2100 & 315 & 1,034 & 1,008 \\
\hline \multicolumn{3}{|c|}{ Average } & 1080 & 846 & 1538 & 333 & & \\
\hline
\end{tabular}

TABLE VI

\begin{tabular}{|c|c|c|c|c|c|c|c|c|c|c|}
\hline \multirow{2}{*}{$\begin{array}{l}\text { No. } \\
\text { of } \\
\text { case }\end{array}$} & \multirow{2}{*}{ Age } & \multirow{2}{*}{ Sex } & \multicolumn{2}{|c|}{ Urine an hour } & \multicolumn{2}{|c|}{$\begin{array}{l}\text { Creatinine } \\
\mathrm{mg} / \mathrm{dl}\end{array}$} & \multirow{2}{*}{$\begin{array}{l}\text { Quant. of } \\
\text { urine per } \\
\text { min. (cc.) }\end{array}$} & \multirow{2}{*}{$\begin{array}{l}\text { GF } \\
\text { cc. }\end{array}$} & \multirow{2}{*}{$\begin{array}{l}\mathrm{RR} \\
\mathrm{cc} .\end{array}$} & \multirow{2}{*}{$\begin{array}{l}\mathrm{RR} \\
\%\end{array}$} \\
\hline & & & $\begin{array}{l}\text { Quant. of } \\
\text { urine (cc.) }\end{array}$ & $\begin{array}{l}\text { Specific } \\
\text { gravity }\end{array}$ & Urine & Plasma & & & & \\
\hline I & 19 & $\delta$ & 515 & 1,003 & 15,44 & 0,87 & 8,5 & 150,8 & 142,3 & 94,3 \\
\hline 2 & 24 & q & 535 & 1,004 & 14,23 & 1,24 & 8,9 & 102,1 & 93,2 & 91,2 \\
\hline 3 & 22 & 우 & 680 & 1,004 & 11,47 & 0,72 & 11,3 & 180,0 & 168,7 & 93,7 \\
\hline 4 & 46 & $\delta$ & 670 & 1,002 & 10,11 & 0,75 & 11,1 & 149,6 & 138,5 & 92,5 \\
\hline 5 & 52 & $\delta$ & 545 & 1,003 & 14,15 & 0,81 & 9,0 & 157,2 & 148,2 & 94,4 \\
\hline 6 & 22 & $\hat{\delta}$ & 530 & 1,005 & 12,23 & 0,90 & 8,8 & 119,5 & 110,7 & 92,6 \\
\hline 7 & 29 & 우 & 560 & 1,003 & 12,07 & 0,65 & 9,3 & 172,7 & 163,4 & 94,6 \\
\hline 8 & 46 & 古 & 625 & 1,002 & 9,15 & 0,64 & 10,4 & 148,6 & 138,2 & 93,0 \\
\hline 9 & 25 & 古 & 625 & 1,008 & 9,16 & 0,81 & 10,4 & 117,6 & 107,2 & 91,1 \\
\hline & & & 587 & & 12,00 & 0,82 & 9,7 & 144,2 & 134,5 & 93,0 \\
\hline
\end{tabular}

normal and so it seems that comparatively much quantity of urine is excreted, though not satisfactorily.

\section{The third group: absorption stage (Tab. VII, VIII)}

The excretion of water is very good. The quantity of urine in 4 hours averages $1423 \mathrm{cc}$. and the most part of it is excreted within the first 2 hours. Besides, in some cases good excretion continues even two hours longer. The maximum quantity of urine in half an hour is over $1 / 3$ of the dosis of drinking water in every case. The quantity of urine in 24 hours is over $1,640 \mathrm{cc}$., showing excessive excretion reaction. The mini- 
On Glomerular Filtration. I

TABLE VII

\begin{tabular}{|c|c|c|c|c|c|c|c|c|}
\hline \multirow{2}{*}{$\begin{array}{l}\text { No. } \\
\text { of } \\
\text { case }\end{array}$} & \multirow{2}{*}{ Age } & \multirow{2}{*}{ Sex } & \multirow{2}{*}{$\begin{array}{l}\text { Quant. of } \\
\text { urine in } 4 \\
\text { hours (cc.) }\end{array}$} & \multirow{2}{*}{$\begin{array}{l}\text { Quant. of } \\
\text { urine in } \\
\text { first } 2 \\
\text { hours (cc.) }\end{array}$} & \multirow{2}{*}{$\begin{array}{l}\text { Quant. of } \\
\text { urine in } \\
24 \text { hours } \\
\text { (cc.) }\end{array}$} & \multirow{2}{*}{$\begin{array}{l}\text { Maximum } \\
\text { quant. of } \\
\text { urine in half } \\
\text { an hour (cc.) }\end{array}$} & \multicolumn{2}{|c|}{ Specific gravity } \\
\hline & & & & & & & Max. & Min. \\
\hline 1 & 25 & 우 & 1300 & 895 & 1640 & 370 & 1,031 & 1,006 \\
\hline 2 & 24 & $\delta$ & 1340 & 1100 & 2085 & 480 & 1,031 & 1,001 \\
\hline 3 & 52 & $\delta$ & 1360 & 930 & 1890 & 385 & 1,030 & 1,003 \\
\hline 4 & 21 & 우 & 1360 & 1055 & 1790 & 450 & 1,031 & 1,001 \\
\hline 5 & 21 & $\delta$ & 1370 & 1195 & 1695 & 420 & 1,033 & 1,002 \\
\hline 6 & 19 & $\delta$ & 1375 & 1125 & 1920 & 610 & 1,032 & 1,003 \\
\hline 7 & 25 & 우 & 1390 & 1045 & 1790 & 580 & 1,032 & 1,010 \\
\hline 8 & 32 & 우 & 1400 & 1090 & 1735 & 350 & 1,032 & 1,002 \\
\hline 9 & 29 & 우 & 1405 & 1010 & 2015 & 390 & 1,026 & 1,006 \\
\hline 10 & 27 & ิे & 1410 & 960 & 1890 & 450 & 1,028 & 1,004 \\
\hline 11 & 29 & 우 & 1475 & 960 & 1965 & 390 & 1,028 & 1,002 \\
\hline 12 & 48 & $\delta$ & 1500 & 1170 & 1940 & 335 & 1,028 & 1,003 \\
\hline 13 & 22 & $\delta$ & 1530 & 1330 & 2000 & 600 & 1,038 & 1,004 \\
\hline 14 & 25 & $\hat{\delta}$ & 1730 & 965 & 2495 & 405 & 1,031 & 1,005 \\
\hline & erag & & 1423 & 1059 & 1921 & 443 & & \\
\hline
\end{tabular}

TABLE VIII

\begin{tabular}{|c|c|c|c|c|c|c|c|c|c|c|}
\hline \multirow{2}{*}{$\begin{array}{l}\text { No. } \\
\text { of } \\
\text { case }\end{array}$} & \multirow{2}{*}{ Age } & \multirow{2}{*}{ Sex } & \multicolumn{2}{|c|}{ Urine an hour } & \multicolumn{2}{|c|}{$\begin{array}{l}\text { Creatinine } \\
\mathrm{mg} / \mathrm{dl}\end{array}$} & \multirow{2}{*}{$\begin{array}{l}\text { Quant. of } \\
\text { urine per } \\
\text { min. (cc.) }\end{array}$} & \multirow{2}{*}{$\begin{array}{l}\text { GF } \\
\text { cc. }\end{array}$} & \multirow{2}{*}{$\begin{array}{l}\text { RR } \\
\text { cc. }\end{array}$} & \multirow{2}{*}{$\begin{array}{l}\mathrm{RR} \\
\%\end{array}$} \\
\hline & & & $\begin{array}{l}\text { Quant. of } \\
\text { urine (cc.) }\end{array}$ & $\begin{array}{c}\text { Specific } \\
\text { gravity }\end{array}$ & Urine & Plasma & & & & \\
\hline 1 & 25 & 우 & 700 & 1,006 & 8,23 & 0,65 & 11,6 & 146,8 & 135,2 & 92,0 \\
\hline 2 & 24 & 今 & 650 & 1,002 & 15,23 & 0,75 & 10,8 & 219,3 & 208,5 & 95,0 \\
\hline 3 & 52 & $\delta$ & 635 & 1,003 & 11,74 & 0,72 & 10,5 & 171,2 & 160,7 & 93,8 \\
\hline 4 & 21 & 우 & 770 & 1,001 & 9,91 & 0,66 & 12,8 & 192,1 & 179,3 & 93,3 \\
\hline 5 & 21 & $\delta$ & 700 & 1,002 & 11,56 & 0,78 & 11,6 & 171,9 & 160,3 & 93,2 \\
\hline 6 & 19 & 古 & 810 & 1,003 & 10,72 & 0,71 & 13,5 & 203,8 & 190,3 & 93,3 \\
\hline 7 & 25 & 우 & 905 & 1,010 & 11,50 & 0,68 & 15,0 & 253,6 & 238,6 & 94,0 \\
\hline 8 & 32 & 우 & 690 & 1,002 & 8,06 & 0,60 & 11,5 & 154,4 & 142,9 & 92,5 \\
\hline 9 & 29 & 우 & 625 & 1,006 & 9,69 & 0,69 & 10,4 & 146,0 & 135,6 & 92,8 \\
\hline 10 & 27 & $\hat{\delta}$ & 740 & 1,004 & 14,64 & 0,82 & 12,3 & 219,6 & 207,3 & 94,3 \\
\hline 11 & 29 & 우 & 750 & 1,002 & 10,83 & 0,64 & 12,5 & 211,5 & 199,0 & 94,0 \\
\hline 12 & 48 & $\delta$ & 635 & 1,003 & 12,19 & 0,70 & 10,5 & 182,8 & 172,3 & 94,6 \\
\hline 13 & 22 & $\delta$ & 985 & 1,004 & 8,52 & 0,60 & 16,4 & 232,8 & 216,4 & 92,9 \\
\hline 14 & 25 & $\delta$ & 610 & 1,005 & 10,07 & 0,62 & 10,1 & 164,0 & 153,9 & 93,8 \\
\hline & & & 729 & & 10,92 & 0,68 & 12,1 & 190,7 & 178,6 & 93,5 \\
\hline
\end{tabular}


mum specific gravity is slightly prevented in 3 cases, but the maximum is normal in every case. GF averages $190.7 \mathrm{cc}$., which is more than normal. This fact shows statistically that the probability of error is below $5 \%$ and so it is significant. RR\% averages 93.5 and so it is a little higher than normal. Therefore polyuria in the absorption stage is mainly due to the increase of GF and the suppression of RR.

I can summarize the above results as follows. In the acute stage the excretion of water is poor, and diluting power is prevented. This oliguria is due to the decrease of GF and the slight suppression of RR. In the middle stage the excretion of water is a little better, and almost normal. In this stage GF decreases, but as RR is suppressed, the excretion of sufficient quantity of water is possible. In the absorption stage the excretion of water is excess owing to the increase of GF and the suppression of RR, though in a few cases the diluting power is a little prevented.

To confirm the above results, I made estimations in several periods of 3 patients who were in hospital for a long time from the beginning of their disease. The first case: 19 years old male patient who entered hospital at the beginning of disease, with a clinical picture indicating the acute stage. As Tab. IX, X show, the quantity of urine increases as the symptom grows slighter. The diluting and concentrating power, prevented at first, becomes normal again. GF, very little at first, grows remarkable afterward. RR suppression, also very little at first, becomes great afterward. The second and third cases show the same process though the grade of each patient is different. That is, in the acute stage of pleurisy the result of water test is bad, but grows better as it progresses, and in the absorption stage it becomes excessive excretion. Therefore it is clear that in the acute stage the change of the quantity of urine is due to the decrease of GF and the slight suppression of $R R$; and in the absorption stage it is due to the increase of GF and the suppression of RR.

\section{Consideration}

Concerning diuresis by water test, Underhill and Pack ${ }^{14)-15)}$ etc. made their experiments on dogs and stated that they could not recognize any hydremia, but I think it is unreasonable in common sense. Hashimoto ${ }^{16)-20}$ and many others proved hydremia by animal and human experiment, concluding that in time of water diuresis, extra-renal total hydremia plays an important part. Concerning the influence of this hydremia upon GF and RR, there are many reports. Poulsson, ${ }^{19}$ Rehberg, Holten ${ }^{21)-25)}$ etc. say that though GF does not increase, RR decreases remarkably. Chrometzka and Unger ${ }^{26)-27)}$ etc. say that GF increases temporally, but decreases after all and that $R R$ suppression becomes remarkable. However, Hiratsuka ${ }^{18}$ recognizes in his experiments on dogs that not only the decrease of $\mathbf{R} R$ 
TABLE IX

\begin{tabular}{|c|c|c|c|c|c|c|c|c|}
\hline \multirow{2}{*}{$\begin{array}{l}\text { No. } \\
\text { of } \\
\text { case }\end{array}$} & \multirow{2}{*}{ Age } & \multirow{2}{*}{ Sex } & \multirow{2}{*}{$\begin{array}{l}\text { Quant. of } \\
\text { urine in } \\
4 \text { hours } \\
\text { (cc.) }\end{array}$} & \multirow{2}{*}{$\begin{array}{l}\text { Quant. of } \\
\text { urine in } \\
\text { first } 2 \\
\text { hours (cc.) }\end{array}$} & \multirow{2}{*}{$\begin{array}{l}\text { Quant. of } \\
\text { urine in } \\
24 \text { hours } \\
\text { (cc.) }\end{array}$} & \multirow{2}{*}{$\begin{array}{c}\text { Maximum } \\
\text { quant. of } \\
\text { urine in } \\
\text { half an } \\
\text { hour (cc.) }\end{array}$} & \multicolumn{2}{|c|}{ Specific gravity } \\
\hline & & & & & & & Max. & Min. \\
\hline 1 & 19 & o & $\begin{array}{r}205 \\
890 \\
1375\end{array}$ & $\begin{array}{r}124 \\
775 \\
1125\end{array}$ & $\begin{array}{r}815 \\
1435 \\
1920\end{array}$ & $\begin{array}{r}35 \\
330 \\
610\end{array}$ & $\begin{array}{l}1,032 \\
1,027 \\
1,032\end{array}$ & $\begin{array}{l}1,024 \\
1,003 \\
1,003\end{array}$ \\
\hline 2 & 25 & t & $\begin{array}{r}495 \\
1295 \\
1730\end{array}$ & $\begin{array}{l}285 \\
970 \\
965\end{array}$ & $\begin{array}{l}1250 \\
2100 \\
2495\end{array}$ & $\begin{array}{l}135 \\
315 \\
405\end{array}$ & $\begin{array}{l}1,032 \\
1,034 \\
1,031\end{array}$ & $\begin{array}{l}1,014 \\
1,008 \\
1,005\end{array}$ \\
\hline 3 & 29 & 우 & $\begin{array}{r}580 \\
1137 \\
1475\end{array}$ & $\begin{array}{l}395 \\
837 \\
960\end{array}$ & $\begin{array}{l}1035 \\
1501 \\
1965\end{array}$ & $\begin{array}{l}150 \\
405 \\
390\end{array}$ & $\begin{array}{l}1,030 \\
1,036 \\
1,028\end{array}$ & $\begin{array}{l}1,012 \\
1,002 \\
1,002\end{array}$ \\
\hline
\end{tabular}

TABLE X

\begin{tabular}{|c|c|c|c|c|c|c|c|c|c|c|}
\hline \multirow{2}{*}{$\begin{array}{l}\text { No. } \\
\text { of } \\
\text { case }\end{array}$} & \multirow{2}{*}{ Age } & \multirow{2}{*}{ Sex } & \multicolumn{2}{|c|}{ Urine an hour } & \multicolumn{2}{|c|}{$\begin{array}{l}\text { Creatinine } \\
\mathrm{mg} / \mathrm{dl}\end{array}$} & \multirow{2}{*}{$\begin{array}{l}\text { Quant. of } \\
\text { urine per } \\
\text { min. (cc.) }\end{array}$} & \multirow{2}{*}{$\begin{array}{l}\mathrm{GF} \\
\mathrm{cc} .\end{array}$} & \multirow{2}{*}{$\begin{array}{r}\mathrm{RR} \\
\mathrm{cc} .\end{array}$} & \multirow{2}{*}{$\underset{\%}{\mathrm{RR}}$} \\
\hline & & & $\begin{array}{l}\text { Quant. of } \\
\text { urine (cc.) }\end{array}$ & $\begin{array}{c}\text { Specific } \\
\text { gravity }\end{array}$ & Urine & Plasma & & & & \\
\hline 1 & 19 & $\delta$ & $\begin{array}{r}62 \\
515 \\
810\end{array}$ & $\begin{array}{l}1,024 \\
1,003 \\
1,003\end{array}$ & $\begin{array}{l}111,67 \\
15,44 \\
10,72\end{array}$ & $\begin{array}{l}1,14 \\
0,87 \\
0,71\end{array}$ & $\begin{array}{r}1,0 \\
8,5 \\
13,5\end{array}$ & $\begin{array}{r}97,9 \\
150,8 \\
203,8\end{array}$ & $\begin{array}{r}96,9 \\
142,3 \\
190,3\end{array}$ & $\begin{array}{l}98,8 \\
94,3 \\
93,3\end{array}$ \\
\hline 2 & 25 & 今 & $\begin{array}{l}135 \\
625 \\
610\end{array}$ & $\begin{array}{l}1,014 \\
1,008 \\
1,005\end{array}$ & $\begin{array}{r}57,33 \\
9,16 \\
10,07\end{array}$ & $\begin{array}{l}1,27 \\
0,81 \\
0,62\end{array}$ & $\begin{array}{r}2,2 \\
10,4 \\
10,1\end{array}$ & $\begin{array}{r}99,3 \\
117,6 \\
164,0\end{array}$ & $\begin{array}{r}97,1 \\
107,2 \\
153,9\end{array}$ & $\begin{array}{l}97,6 \\
91,1 \\
93,8\end{array}$ \\
\hline 3 & 29 & 우 & $\begin{array}{l}270 \\
560 \\
750\end{array}$ & $\begin{array}{l}1,012 \\
1,003 \\
1,002\end{array}$ & $\begin{array}{l}18,06 \\
12,07 \\
10,83\end{array}$ & $\begin{array}{l}0,85 \\
0,65 \\
0,64\end{array}$ & $\begin{array}{r}4,5 \\
9,3 \\
12,5\end{array}$ & $\begin{array}{r}95,6 \\
172,7 \\
211,5\end{array}$ & $\begin{array}{r}91,1 \\
163,4 \\
199,0\end{array}$ & $\begin{array}{l}95,3 \\
94,6 \\
94,0\end{array}$ \\
\hline
\end{tabular}

but also the increase of GF is the cause of water diuresis. Like this, the theories do not agree, as to the cause of diuresis in the water test.

I estimated GF and RR of healthy persons neither making water test nor loading creatinine and obtained the value of GF $129.5 \mathrm{cc}$. and $\mathrm{RR} \%$ 98.6, but estimating GF and $\mathrm{RR}$ when the quantity of urine is maximum by loading water, I had the value of GF $167.8 \mathrm{cc}$. and RR\% 92.5. This result is statistically significant as I have already stated. Therefore I cannot but support Hiratsuka's theory that the increase of the quantity of urine by water test is caused not only by the RR suppression but also by the increase of GF.

As is well known, there is oliguria in the acute stage and polyuria in the absorption stage of pleurisy, so by estimating the daily quantity of urine, we can imagine the condition of pleura to some degree. But when the absorption of exudate lasts long, there is no remarkable change in the 
daily quantity of urine, and so it is not always possible to imagine the condition of pleura. However, Peyrer and others tested pleuritic patients by Volhard's water test and estimating the quantity of urine in 4 hours and 12 hours, they found the quantity is very little compared with the dosis of drinking water in the acute stage, and remarkably much in the absorption stage; which, they asserted, is helpful for deciding when pleurocentesis should be done, and consequently gives some therapeutic effect. But they mainly treated of the change of the quantity of urine and did not refer to the mechanism of urine in the kidney by water test. They did not make clear whether it is owing to the decrease of GF or to the extreme acceleration of RR though GF is normal, that the quantity of urine in 4 hours is so much less than the dosis of drinking water in the acute stage. Nor did they make clear whether it is owing to increase of GF or to the suppression of RR or to both, that the quantity of urine in 4 hours is so excessive in the absorption stage. These problems have been solved by my experiment.

Next, I tried to make a theoretical examination on the way of cure from the result of my experiment. There is no doubt that the change of GF and RR in pleurisy is due to the abnormality of exudation and resorption at the very locality where pleurisy exists, but judging from the fact that in many pleuritic patients we sometimes find temporary nephritic symptom caused by tubercular allergy, I think it can be concluded that in the case of pleurisy there occurs an abnormality of the function of kidney as one of the symptoms of allergy, which causes the change of GF and RR.

Now, as oliguria in the acute stage occurs on account of the decrease of GF and the slight suppression of RR, we ought to try to increase GF and to decrease $R R \%$ for the purpose of increasing the quantity of urine. Consequently we are suggested to dose Euphyllin which is believed to expedite diuresis, or Salyrgan which is believed to suppress RR. But as Nonnenbruch ${ }^{28}$ says, the genesis and absorption of pleural exudate is not due to the total water metabolism but to the partial condition of the patient, and when the inflammation is severe, it is impossible to change oliguria into polyuria and moreover it is more reasonable to keep the kidney quiet than to stimulate it which is very sensitive on account of allergy; so I do not think it is very effective to dose diuretic carelessly in such a case. Besides, with the exception of Trousseau's indication, there are pro and con views as to the removal, by puncture, of the liquid produced in the acute stage. Mumme and others say, according to their experiments, that pleurocentesis is not advisable in the acute stage when oliguria is found by water test, and I myself have the same opinion, because in the acute stage the liquid is easily produced again if it removed by puncture. Again I 
found that the water test in the acute stage does not show any side action, though $I$ had an experience of finding the decrease of the quantity of urine for one or two days after the test, which however became normal soon again.

In the middle stage there is a decrease of GF though the suppression of $R R$ is enough, so that administration of Euphyllin can be expected as it is helpful to increase GF. Besides, I have an interesting experience that soon after the trying of water test in this stage the quantity of urine increases remarkably sometimes, because the water test itself becomes the means of water thrust test, expediting reabsorption so much.

Finally, in the absorption stage there is sometimes a want of $R R$ suppression, though GF is enough, so by suppressing $R R$ more, greater quantity of urine can be produced. Therefore the administration of Salyrgan is reasonable, as it is helpful to suppress RR. In this case too, there are some cases in which water test itself becomes water thrust test, which therefore needs no other means.

\section{ConCLUSION}

In the acute stage of wet pleuritic patients the result of water test is bad. The oliguria in this stage is due to the decrease of glomerular filtration and to the decrease of the suppression of the kidney reabsorption. In the absorption stage the excretion of urine is excess. This is due to the excessive increase of glomerular filtration and to the suppression of reabsorption of the kidney. From this foundation I have referred to the way of cure.

Summarising this, I can say that in the clinical treatment of pleuritic patients the water test and the estimation of glomerular filtration and reabsorption of the kidney do not give any unpleasant influence to the patients, but help to decide whether they are in the acute stage or in the absorption stage, and consequently give suggestions to the way of cure, and moreover give sometimes a good influence to them as means of water thrust test.

\section{References}

1) Peyrer, Med. Klin., 1924, 19, 637.

2) Greuel, ibid., 1925, 21, 1080.

3) Mumme, Beitr. Klin. Tbk., 1932, 79, 619.

4) Hirai, Rinsho Igaku, 1932, 20, 153.

5) Inada, Shindan to Chiryo, 1935, 22, 626.

6) Okamoto, Zikken Iho, 1937, 24, 462.

7) Ueda, Nippon Izi Shimpo, 1938, No. 813, 1220.

8) Matsue, Hiroshimabyoin-Dokokaiho, 1935, 3, 7.

9) Okazaki, Okayama Igaku Kaishi, 1926, No. 432-443, 221. 
10) Rehberg, Biochem. Ztschr., 1926, 20, 447, 461.

11) Nakazawa and Kusakari, Tohoku J. Exp. Med., 1930, 16, 321.

12) Asano, Zikken Tho, 1942-43, 29, 339.

13) Hiratsuka, Tohoku J. Exp. Med., 1937, 31, 153.

14) Underhill and Pack, Am. J. Physiol., 1923, 66, 520.

15) Haldane and Priestley, J. Physiol., 1916, 50, 296.

16) Hashimoto, Arch. exp. Path. u. Pharm., 1914, 76, 367.

17) Daniel and Högler, Wien. Arch. inn. Med., 1922, 4, 167.

18) Marx, Klin. Wschr., 1925, 2339.

19) Poulsson, Z. ges. exp. Med., 1930, 71, 577.

20) Abe, Tohoku J. Exp. Med., 1931, 17, 174.

21) Rehberg and Holten, Acta Med. Scand., 1931, 74, 479, 538.

22) Bauer, Medvei and Taubenhaus, Klin. Wschr., 1935, 1001.

23) Fremont et al., J. Clin. Invest., 1931, 9, 7.

24) Cambier, Ann. Méd., 1933, 34, 360; 1934, 35, 273.

25) Popper, Klin. Wschr., 1937, 1454.

26) Chrometzka and Unger, Z. exper. Med., 1932, 80, 261.

27) Taubenhaus, Z. klin. Med., 1935, 128, 98.

28) Nonnenbruch, Z. Tbk., 1928, 50, 193. 